\title{
Antimicrobial activity of Leuconostoc mesenteroides biofilm against different microorganisms
}

\author{
Asmaa Sabah Ahmaed \\ Abdullah Ismaeel Awad \\ Food Science / College of Agricultural Engineering Sciences / University of Baghdad \\ E-mail: asmsabah@yahoo.com, abdu20110@yahoo.com
}

\begin{abstract}
Back ground: Leuconostoc is one of the species of lactic acid bacteria that produced biofilms.Probiotic bacteria that produced biofilm has been used as naturopathy against different microbial pathogens. Objective: This study was conducted to determine the antimicrobial activity of Leuconostoc biofilm, against 24 isolates (4 of 6 different types) of food borne pathogens including Staphylococcus aureus, Salmonella spp, Escherichia coli, Klebsiella spp, Pseudomonas aeruginosa, Streptococcus mutans, Bacillus subtillus, Bacillus cereus, Bacillus sterothermophillus and Candida albicans.

Materials and methods: using various concentration in vitro by filter paper disk diffusion method .

Result: The present study showed the potent antimicrobial activity of the Leuconostoc mesenteroides biofilm against the all tested bacterial pathogens except Bacillus species and yeast Candida albicans. Biofilm produced by Leuconostoc mesenteroides showed highest zone of inhibition (13mm) against

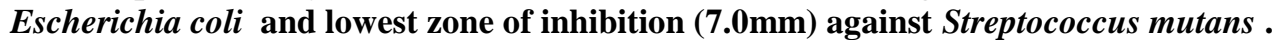

Conclusion: Consequently, Leuconostoc mesenteroides biofilm may be used as an antimicrobial agent in food products to prevent spoilage.

Keywords: Biofilm, Dextran, Exopolysaccharide, Leuconostoc mesenteroides, Antimicrobial activity.

\section{Introduction}

Biofilms are defined as microbial communities characterized by the cells that are attached to each other, embedded in a matrix of Extracellular Polymeric Sub-stances (EPS) (1).Lactic acid bacteria could produce bio-film. The most important part of the biofilm matrix, are extracellular polysaccharides (2). Leuconostoc mesenteroides biofilm matrix contains components dextran, proteins and nucleic acids (3), and had an active action against many microbes, fungus, viruses and parasites. It was found that this biofilm had more effect on gram negative bacteria such as Escherichia coli ,Pseudomonas aeruginosa, Proteus mirabilis, Shigella flexneri ,Campylobacter jejuni, Salmonella typhimurium and gram positive bacteria such as Staphylococcus aureus, Staphylococcus epidermidis ,Enterococcus faecalis (1). While the study of Hitendra (4) reported that Leuconostoc bacteria had antibacterial activity against Xanthomonas spp , Erwinia spp and some spoilage molds. Some Leu. mesenteroides sp. mesenteroides strains were found to have inhibitory activity against Aeromonas hydrophila, Pseudomonas aeruginosa and Shewanella putrefaciens (6). Many strains of Leuconostoc mesenteroides showed a high ability to inhibit Listeria spp. because they produce bacteriocin (leucocin B)(7). This study aimed to observe the effect of Leuconostoc mesenteroides biofilm on the growth of some bacteria and fungi that cause food spoilage.
\end{abstract}

\section{Materials and methods}

\section{Biological material}

In this study, Leuconostoc mesenteroides sub sp mesenteroides was isolated from Sauerkraut and then identified by using cultural, microscopical and biochemical tests according to (8).

Cultivation conditions

The cultivation of Leuconostoc mesenteroides bacteria is usually performed in MRS medium $(9,10)$.

Production of biofilm

Biofilm production was achieved according to the standard mix of Awad and Ahmaed (11) method as follows : Modified MRS medium by addition $10 \%$ sucrose.

\section{Preparation of different concentrations of biofilm}

Different concentrations were prepared from Leuconostoc mesenteroides biofilm $(1: 2,1: 3,1: 4)$ in addition of stock concentration, while the bacteria were poured in sterilized petridishes and maintained after hardening at $4{ }^{\circ} \mathrm{C}$ petridish considered to be as control sample (12).

- Study of antibacterial activity for different concentrations of biofilm

Stage 1

The test isolates bacteria were activated by transferring loopfull to the Nutrient broth from agar medium and incubated tubes in 37C for 18 hours (6) while yeast activated by transferring loopfull to PDA medium and incubated in $28 \mathrm{C}$ for 24 hours. 


\section{Stage 2}

Filter paper disk diffusion Method was adopted by spreading $0.1 \mathrm{~mL}$ of test bacteria on Nutrient Agar (NA) while test yeast on PDA using L-shaped glass rode.4-6 sterilized paper disks (Whitman No.3) were prepared for each petridish at a diameter of $5 \mathrm{~mm}$ and each disk placed on the culture medium was loaded with $10 \mu \mathrm{L}$ from different concentrations of Leuconostoc mesenteroides biofilm by micropipette(13) . All petridishes were incubated at $37^{\circ} \mathrm{C}$ for $24 \mathrm{hrs}$ for bacteria and $28^{\circ} \mathrm{C}$ for $48 \mathrm{hr}$ for fungi. Diameters of clear zones were calculated (14).

- Study of antifungal activity for different concentrations of biofilm

This activity was examined using Poisoned Food Technique(15) which relied on the radial growth of tasted molds by placing a piece of $0.5 \mathrm{~cm}$ from a fungal culture at age of 5 days in the centre of cultural medium. Petridishes were incubated at $25{ }^{\circ} \mathrm{C}$. The diameter of fungal culture of control treatment calculated as it reaches the edge of peridish. Colonies diameters were calculated. The inhibition percentage was determined as following equation:

$\%$ Inhibition= growth diameter rate of control sample - growth diameter rate of treatment sample*100

\section{Results and discussion}

In this study nine types of bacteria were used Five gram positive bacteria : Staphylococcus aureus, Streptococcus mutans, Bacillus subtilis, Bacillus cereus,Bacillus stearothermophilus and four gram negative bacteria : Pseudomonas aeruginosa ,Salmonella spp. ,Escherichia coli, Klebsiella spp. In addition one yeast (Candida albicans). Results showed the inhibitory activity of Leuconostoc mesenteroides biofilm against Staphylococcus aurues by using different concentrations as the inhibition continued until 1:4 (Figure (1)and Table (1)). Diameters of clear zones were $(12,11,10,8) \mathrm{mm}$ consequently.It also showed antibacterial activity of E.coli and Pseudomonas aeruginosa. The effectiveness of biofilm against Staphylococcus aurues may be due to metabolic products of bacteria Leuconostoc mesenteroides such as organic acids , diacetyl, CO2,hydrogen peroxide , and secondary metabolites (such as bacteriocin) (2). The gram negative bacteria (E.coli) were highly sensitive to the biofilm for all concentrations $(13,11,11,8)$ $\mathrm{mm}$. While diameters of clear zones of growth of Pseu. aeruginos were $(11 \mathrm{~mm}, 10 \mathrm{~mm}, 10 \mathrm{~mm}$ and $9 \mathrm{~mm})$ consequently using different concentration of biofilm. Leuconostoc mesenteroides has highly inhibitory effect against E.coliATCC25922 and Pseu. aeruginosaATCC27853 and may be due to its production biosurfactant that has antimicrobial activity (16).It can also damage the cell membrane by interfering with phospholipids and membrane proteins (17). The results showed the ability of biofilm to inhibit the Streptococcus mutans in diameters of clear zones $7 \mathrm{~mm}$ and $6 \mathrm{~mm}$ of the first two concentrations. This is confirmed by Kang et al.,(18) that appear Leuconostoc mesenteroides can production exopolysaccharides especially soluble dextran (11). It discourages the formation of a biofilm matrix .Many Leuconostoc mesenteroides species produce many organic acids in addition to a group of antimicrobial compounds ,especially protein products called bacteriocines and like bacteriocines (such as Carnosin and Leuconocin) . This compound inhibited wild group of gram negative and positive bacteria $(19 ; 2)$. Bacteriocins disrupts the cell wall system ,inhibits proteins or synthesizes nucleic acids.It can bind to cell wall components such as lipid molecules or surface sites sutible for binding, leading to direct cell degradation and thus reduced bacterial counts (20). All Bacillus spp. was not affected by all biofilm concentrations because it counts as a spore former bacteria and this might due to its special mechanism that qualified these bacteria to resist the active materials existing in Leuconostoc mesenteroides biofilm . 


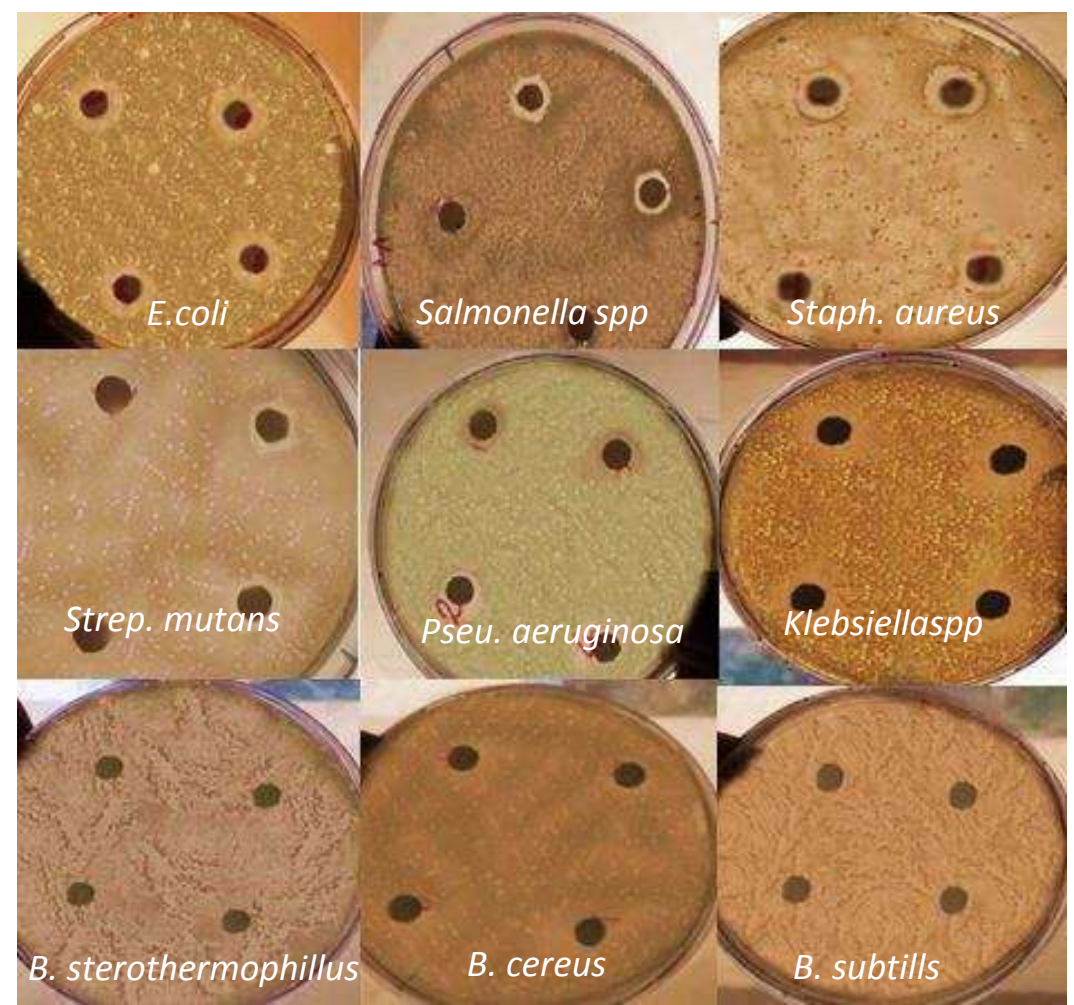

Figure (1): Inhibitory activity of Leuconostoc mesenteroides biofilm through clear zone

Table (1): Effect of Leuconostoc mesenteroides biofilm on some types of studied bacteria using disks paper method

\begin{tabular}{|c|c|c|c|c|}
\hline \multirow[b]{2}{*}{ Bacteria type } & \multicolumn{4}{|c|}{ Growth inhibition clear zone average } \\
\hline & $1 \mathrm{ml}$ biofilm & $1: 2$ & $1: 3$ & $1: 4$ \\
\hline Staph.aureus & 12 & 11 & 10 & 8 \\
\hline Salmonella spp & 10 & 9 & NZ & NZ \\
\hline E.coli & 13 & 11 & 11 & 8 \\
\hline Klebsiella spp & 10 & 10 & 9 & 8 \\
\hline Pseu.aeruginosa & 11 & 10 & 10 & 9 \\
\hline Strep.mutans & 7 & 6 & NZ & $\mathbf{N Z}$ \\
\hline B.subtilis & NZ & NZ & $\mathbf{N Z}$ & $\mathbf{N Z}$ \\
\hline B.cereus & NZ & NZ & NZ & NZ \\
\hline B.sterothermophillus & NZ & NZ & NZ & $\mathbf{N Z}$ \\
\hline Candida albicans & NZ & NZ & NZ & NZ \\
\hline
\end{tabular}

*Inhibition disk is not involved the diameters of clear zones $\mathbf{N Z}=$ No Zone 
Results of Figure (2) showed that the inhibitory activity percentage of Leuconostoc mesenteroides biofilm against Penicillium spp. mold as it reached $70.21 \%$. That was higher than against Aspergilus niger mold as it reached $55.33 \%$ that what confirmed Hitendra et al .,(19) who observed that metabolic products for Leuconostoc mesenteroides such as bacteriocins Antifungal activity was attributed to many metabolitic products such as organic acids (that reduce $\mathrm{pH}$ ), $\mathrm{H}_{2} \mathrm{O}_{2}, \mathrm{CO}_{2}$, diacetyle and bacteriocins(21).

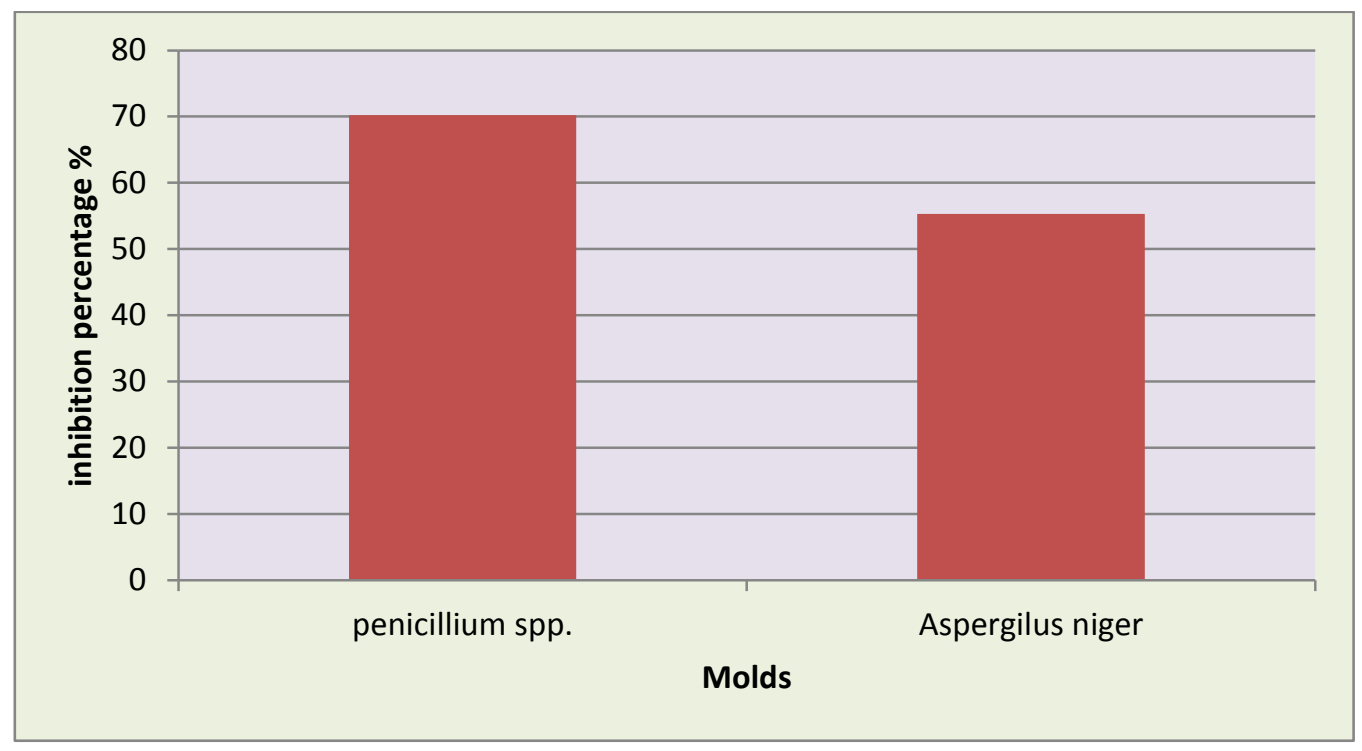

Figure (2): Effect of Leuconostoc mesenteroides biofilm on inhibition of some molds

\section{Reference}

1. Triveda L, Gomathi S. Detection of biofilm formation among the clinical isolates of Enterococci: An evaluation of three different screening meth-ods. International J. of Current Microbiology and Applied Sciences. (2016);5(3): 643-650.

2. Abekhti A, Daube G, Kihal M. Isolation and identification of dominant osmophilic Leuconostoc strains from traditional date product" Btana". International Food Research J.. (2014); 21(4): 1297 1304.

3. Awad AI, Ahmaed AS. Studying optimum conditions for biofilm production from Leuconostoc mesenteroides. J. of Research in Ecology. (2018); 6 (2):2185-2191.

4. Hakeem IM. Using tea and Christ thorm extract as antioxidants to improve the keeping quality of soft cheese and cream. M.S Thesis. University of Baghdad. College of Agriculture. Dep. Food Sci. (2006):118.

5. Al-Delaimy KS, Ali SH. Antibacterial action of vegetable extracts on the growth of pathogenic bacteria. J. of the Science of Food and Agriculture (1970); 21(2): 110-112.

6. Allameh SK, Daud H, Yusoff FM, Saad CR, Ideris A. Isolation, identification and characterization of Leuconostoc mesenteroides as a new probiotic from intestine of snakehead fish (Channa striatus). Afr. J. Biotechnol. (2012)11: 3810-3816.

7. Ahmad V, Khan MS, Jamal QMS, Alzohairy MA, Al Karaawi MA, Siddiqui MU. Antimicrobial potential of bacteriocins: in therapy, agriculture and food preservation. International $\mathrm{j}$. of antimicrobial agents. (2017); 49(1): 1-11.

8. Badel S, Laroche C, Gardarin C, Bernardi T ,Michaud P. New method showing the influence of matrix components in Leuconostoc mesenteroides biofilm formation. Applied Biochemistry and Biotech-nology. (2008)151(2-3): 364-370.

9. Cholakov R, Tumbarski Y, Yanakieva V, Dobrev I, Salim Y, Denkova Z. Antimicrobial activity of Leuconostoc lactis strain BT17, isolated from a spontaneously fermented cereal beverage (boza). The J. of Microbiology, Biotechnology and Food Sciences. (2017); 7(1): 47. 
10. Mahmmod IA. Effect of plant extracts on som fungi causing plant diseases. M.S Thesis. University of Baghdad.College of Agriculture(1985).

11. Salman J, Khudair A. Antibacterial and anti-biofilm effect of biosurfactant produced from Leuconos-toc mesenteroides ssp. cremoris against bacteria from catheters. World J. of Pharmaceutical Re-search. (2015); 4990(10): 320-333.

12. Allawi SS. Influence of black seed extracts in some microorganisms and shelf life of cheese. The Iraqi J.of Agri-Sci. (2008);39: 124-133.

13. Garvie EI. Bergeys Manual of Systematic Bacte-riology: Gram positive cocci. Genus Leuconostoc. Eds. P.H. Sneath, N.S. Mair and M.E. Sharpe, Williams-Wilkins, Baltimore. (1986); 2: 1071.

14. Adebayo-tayo BC, Abiodun Onilude A. Screening of lactic acid bacteria strains isolated from some Nigerian fermented foods for EPS production. World Applied Sciences J.. (2008); 4(5): 741-747.

15. Ahmead AS, Allawi SS, Hassan SC. Effect of orange peel extract on some microorganisms causing food spoilage and its role in shelf life of Iraqi bread. The Iraqi J. of Agriculture Sci. (2010); 41 (3): 105-115.

16. Latfabad TB, Shahcheraghi F, Shooraji F. Assessment of antibacterial capability of rhamnolipids produced by two indigenous Pseudomonas aeruginosa strains .Jundishapur J. Microbiol. (2013); 6(1):29-35.

17. Salas-Jara MJ, Ilabaca A, Vega M, García A. Biofilm forming Lactobacillus: new challenges for the development of probiotics. Microorganisms. (2016); 4(3): 35.

18. Kang MS, Kang IC, Kim SM, Lee HC, Oh, J. S. Effect of Leuconostoc spp. on the formation of Streptococcus mutans biofilm. The J. of Microbiology. (2007); 45(4), 291-296.

19. Hitendra J, Suvarna VC, Niveditha SB. Antimicrobial Attributes of Leuconostoc Isolates against Fruit and Vegetable Spoilage Organisms. Int. J. Curr. Microbiol. App. Sci. (2015); 4(11): 160-166.

20. Benmechernene Z, Chentouf HF, Yahia B, Fatima G, Quintela-Baluja M, Calo-Mata P, BarrosVelázquez J.. Technological aptitude and applications of Leuconostoc mesenteroides bioactive strains isolated from Algerian raw camel milk. BioMed research international. ( 2013).

21. Slížová M, Nemcová R, Mad'ar M, Hadryová J, Gancarčíková S, Popper M, Pistl J. Analy-sis of biofilm formation by intestinal lactobacil-li. Canadian j. of microbiology.(2015)6;1(6): 437-446. 